\title{
The evaluation of compounding prescription and its availability of a licensed product for children at a private hospital in Yogyakarta, Indonesia
}

\author{
Dina Christin Ayuning Putri, Maria Dorensia Ku Nanga, Sri Hartati Yuliani \\ Faculty of Pharmacy, Sanata Dharma University, Yogyakarta Special Region, Indonesia,
}

Keywords
Compounding
Extemporaneous preparation
Licensed drug formula
Prescribing profile
Correspondence
Dina Christin Ayuning Putri
Faculty of Pharmacy
Sanata Dharma University
Yogyakarta Special Region
Indonesia
dinachristin@usd.ac.id

Keywords

Compounding

Licensed drug formula

Prescribing profile

Correspondence

Dina Christin Ayuning Putri

Faculty of Pharmacy

Sanata Dharma University

Indonesia

dinachristin@usd.ac.id

\section{Introduction}

Providing medicine for paediatric patients is a huge challenge, including the lack of information on drug dosages and the availability of dosage to form the formulas. Medication errors and serious risks are also more common in children than adults (C. Wiedyaningsih et al., 2012). Besides, the need for treatment in paediatric patients is certainly not the same as in adults because the physiology of the paediatric patients' bodies must be considered different in terms of pharmacokinetics, dosage, route of administration and adherence. That is the reason why a study for paediatric medication is required.

An extemporaneous preparation or compounded drug is commonly used as a medication for paediatrics (Widyaswari \& Wiedyaningsih, 2012). Compounding is an activity of changing dosage form or mixing drugs into a new dosage form which is needed for the patient (Jackson \& Lowey, 2010). It has a high risk and should be of concern because there are many undesirable events such as pharmaceutical problems, drug interactions, medication errors, quality of concoctions, and bacterial contamination problems. However, drug compounding is generally a solution to the limitation of drug formulas for paediatrics (C. Wiedyaningsih et al., 2012).

There are some alternatives to drug compounding for paediatric patients. Divided medicinal powder, syrup, dispersible powder/tablet, etc., are some dosage formulations that are commonly used. The study from Virginia (2014) showed that $73 \%$ of paediatric patients were more likely to get divided medicinal powder as a medication. Divided medicinal powder, also known as "puyer" in Indonesia, has several advantages, such as flexibility in dose adjusting, easy administration, and 
simplicity to use (Virginia, 2014). However, it also has some disadvantages, including the possibility of adverse events, drug interactions, incompatibilities, and other risks (Rochjana et al., 2019).

A study of the profile and determinants of compounding services in the Yogyakarta Special Region showed that most community pharmacists (94\%) dispensed prescriptions with compounding. Prescription-required compounding accounted for $11.55 \%$ of prescriptions dispensed within one month (Kristina et al., 2018). There is a high risk of medication error with compounding. This high compounding frequency rate and its risk make it important to do research on the profile of the compounding prescription in every health facility. The risk and negative effects of drug compounding should be minimised by using a licensed product for paediatric medication. Thus, it is necessary to carry out an analysis of the availability of licensed products for medicines formulated in a pharmaceutical installation. Studies have been conducted regarding the profile of the compounding prescription and also the evaluation of its availability as licensed products in a primary health facility in Yogyakarta (Widyaswari \& Wiedyaningsih, 2012). In that study, it was found that there are still some drugs intended for children, not available in the form of a licensed formula.

This study aimed to determine and evaluate the compounding prescription profile, especially in divided medicinal powder form, and its availability as a licensed product in a public hospital in Yogyakarta Special Region. The results of this study are expected to provide long-term benefits in decreasing the frequency of compounding drugs for active substances available in licensed dosage forms for children.

\section{Methods}

This study was an analytical observation with a retrospective cross-sectional design. This study had an ethical clearance certificate from the Ethical Commission of the University of Respati Yogyakarta, no 130.3/FIKES/PL/V/2019. The population were all prescribed medicines in the hospital. The samples of prescriptions were collected by purposive sampling method in a pharmacy department at a public hospital in Yogyakarta Special Region. The inclusion criteria for the sample was that prescriptions contain an order to compound the divided medicinal powder for paediatric patients (0-18 years old) from January to March 2019. The exclusion criteria were unreadable prescriptions (illegible handwriting).

After the data were collected, they were analysed descriptively into two sections, including: a. The profile of divided medicinal powder prescription:

The profile analysis of prescription includes the characteristics of the subject, the age, the number of compounding, and the number of active substances contained in the preparations. The data were analysed descriptively and presented in the form of tabulation of frequency and percentage.

b. The analysis of the availability of a licensed product for paediatric patients:

The availability of the licensed product for paediatric patients (syrups, dry syrups, powder drops, suspensions, lozenges, and chewable tablets) was seen from the literature. The literature was MIMS Consultation Guidelines 2019/2020 and ISO Indonesia volume 52 (2019).

\section{Results}

In this study, the profile of divided medicinal powder prescriptions was analysed from all prescriptions that met the inclusion criteria. There are 152 prescriptions from the observation. In Figure 1, the profile of the subject was clearly shown that compounded drug was highly prescribed for paediatrics under five years old. Meanwhile, there are about $3 \%$ of the patients with the age range $12-18$ years old also get a divided medicinal powder. a. Age distribution

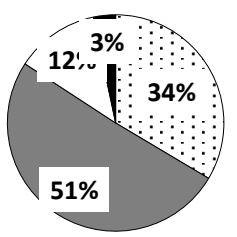

$\square$ 6-11 years old $\quad$ 12-18 years old $\square$ 0-1 year old $\square$ 2-5 years old b. Number of the active substance

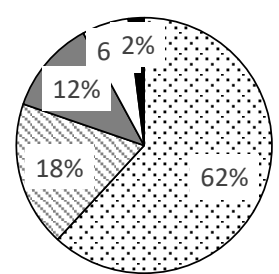

$\square 1$ Active subtance $\quad \mathbf{2}$ Active subtances $\square 3$ Active subtances $\square 4$ Active subtances 5 Active subtances

\section{Figure 1: The profile of compounding prescription}

The number of active substances that were compounded in one dosage form was also analysed. It was shown that more than half of all compounded drugs were containing one active substance. The highest number of active ingredients containing in a prescription were five substances; this kind of prescription-only appear in a low frequency (2\%).

The availability of the licensed product for paediatric patients was analysed from all the active substances that compounded. The results showed that from 152 
prescriptions obtained; there are 38 active substances prescribed for compounding (Table I). The top five frequently prescribed were Triamcinolone,
Phenobarbital, Salbutamol Sulfate, Levotiroksin sodium, and Bromheksin. Most of them were drugs that indicated respiratory disease.

Table I: Active substances that undergo compounding along with the frequency of prescription

\begin{tabular}{|c|c|c|c|c|c|}
\hline Active substances & Frequency & Percentage & Active substances & Frequency & Percentage \\
\hline Triamcinolone & 45 & $17.65 \%$ & Ambroxol $\mathrm{HCl}$ & 2 & $0.78 \%$ \\
\hline Salbutamol Sulfate & 25 & $9.80 \%$ & Loratadine & 2 & $0.78 \%$ \\
\hline Levotiroksin Sodium & 17 & $6.66 \%$ & Lisinopril & 2 & $0.78 \%$ \\
\hline Bromheksin & 15 & $5.88 \%$ & Spironolactone & 2 & $0.78 \%$ \\
\hline Terfenadine & 12 & $4.70 \%$ & Triheksiphenidil & 2 & $0.78 \%$ \\
\hline Pseudoephedrine $\mathrm{HCl}$ & 12 & $4.70 \%$ & Ursodeoksikolat & 2 & $0.78 \%$ \\
\hline Captopril & 10 & $3.92 \%$ & Risperidone & 2 & $0.78 \%$ \\
\hline Piracetam & 9 & $3.52 \%$ & Vitamin B6 (Pyridoxine) & 1 & $0.39 \%$ \\
\hline Cefixime & 9 & $3.52 \%$ & Alprazolam & 1 & $0.39 \%$ \\
\hline Phenytoine & 7 & $2.74 \%$ & Buspirone & 1 & $0.39 \%$ \\
\hline Cetirizine & 5 & $1.96 \%$ & Haloperidol & 1 & $0.39 \%$ \\
\hline Asam Folat & 5 & $1.96 \%$ & Amoxicillin & 1 & $0.39 \%$ \\
\hline Diazepam & 4 & $1.56 \%$ & Mebendazole & 1 & $0.39 \%$ \\
\hline Mebhydrolin & 4 & $1.56 \%$ & Clindamicin & 1 & $0.39 \%$ \\
\hline Vitamin B1 (Thiamin) & 4 & $1.56 \%$ & Clobazam & 1 & $0.39 \%$ \\
\hline Paracetamol & 3 & $1.17 \%$ & Levotiroksin & 1 & $0.39 \%$ \\
\hline Niacin & 3 & $1.17 \%$ & Isoniazid & 1 & $0.39 \%$ \\
\hline
\end{tabular}

\section{Discussion}

The profile of divided medical powder prescriptions was analysed from the subject (patients) and the object (drug). In this study, 152 prescriptions suited the inclusion criteria to analyse its profile. The profile of the prescription was presented in Figure 1. It was shown that children from 0-5 years old were likely to get a divided medicinal powder as the medication. It is reasonable because, at those ages, they may have difficulty in taking a tablet or comply when given more than one drug (dosage form). Besides, the licensed product is also considered expensive (Setyani \& Putri, 2019; C. Wiedyaningsih et al., 2012). This phenomenon was also shown in a study by Piliarta (2012), which stated that children under five years old tended to get compounded drugs than the older children (Piliarta et al., 2012). Meanwhile, there are about 3\% of the patients with the age range $12-18$ years old also get a divided medicinal powder. At this age, children should be able to get a pill or tablet as a medicine to reduce the number of compounded drugs.
The divided medicine powder can contain one or more active substances, which are mixed into one dosage form. The amount of active substances given to the patient depends on the severity and the doctor's diagnosis based on the symptoms and condition of the patient (C. Wiedyaningsih et al., 2012). An analysis of the number of active substances in each prescription is useful to evaluate the prescription profile. There were $62 \%$ of prescriptions that were prepared with only one active substance. As seen in Figure $1 b$, the compounding order containing five active substances had the lowest frequency. This result shows that compounding practice in the hospital has compromised the potency of the compounded drug, thus increasing incompatibility and instability. The incompatibility and instability in the compounded drug will increase as more active substances are added (Setyani \& Putri, 2019; C. Wiedyaningsih et al., 2012).

Compounding drugs using one type of active substance is usually carried out for several reasons, such as because of the limited licensed preparations for 
children (syrup, drop) or because the available licensed preparations are not affordable (Setyani \& Putri, 2019). In this study, the active substances that were compounded were recorded, and their frequency was calculated. From the 152 collected prescriptions, 38 active substances were compounded (Table I). These active substances were then examined for their availability in licensed products for paediatric patients.

Based on Table I, the five types of active substances mostly compounded into divided medicine powder were Triamcinolone acetonide as an anti-inflammatory drug, Phenobarbital as antiepileptic, Salbutamol as an anti-asthmatic drug, Levotiroxin $\mathrm{Na}$ as an antithyroid drug to treat hyperthyroidism, and Bromhexine as a mucolytic agent. In March 2020, it appeared that there are certain drug prescriptions that are higher than other months. It is because the weather and climatic condition in Yogyakarta Special Region from January to March 2020 was cold and rainy. It caused the children with low immunity to have a common cold, asthma, rhinitis allergic, etc. It was reasonable that these drugs have a high prescribing frequency. The results of this study are in line with the research of Wiedyaningsih and Oetari (2005), who also found that compounded drugs are prescribed primarily for the purpose of treating respiratory diseases and allergies.(Chairun \& Wiedyaningsih. 2005).

The availability of licensed products for paediatric patients was analysed from all the active substances that were compounded. The results showed that from 152 prescriptions obtained, 38 active substances were prescribed for compounding (Table 1). The evaluation of their availability in licensed products for paediatrics based on the literature (MIMS Consultation Guidelines 2019/2020 and ISO Indonesia volume 52 (2019) showed that four drugs were not available for paediatrics. Specifically, these drugs were not available in a single composition with a suitable dosage form for children, and there was no available information on the paediatric dose. These four drugs were Thiamin, Niacin, Pyridoxine, and Buspirone. However, the other active substances that were available in licensed products were still compounded.

There are some limitations in this study that might be improved. Observation for the reason to compound the drug from the doctor should also be considered in this study. It will give more information why a lot of drug which already available in the licensed product was still compounded. Drug compounding has some issues about the stability of the compounded products, the accuracy in dose strength, and the lack of standard protocol (Gudeman et al., 2013; Kristina et al., 2017). The pharmacy department should conduct a risk assessment of active substances that are routinely used or have a high frequency of compounding. It may prevent medication errors in the dispensing stage. If the results of the risk assessment and risk analysis show that there is a potential risk (either related to quality, efficacy, or safety) to the compounded drugs, it will be better if the drugs are delivered with the available licensed products to minimise or eliminate the risks (Jackson \& Lowey, 2010).

\section{Conclusion}

The profile of divided medical powder prescriptions in this hospital from January to March 2020 were mostly written for paediatrics patients under five years old. The most compounded drug contained one active substance. There are 34 active substances available as licensed products for children. However, there are four active substances that are not available as licensed products for children, namely Thiamin, Niacin, Pyridoxine, and Buspirone. The results of this study are very useful for hospitals to identify what drugs are actually available in licensed products, to minimise the frequency of compounding and reduce the risk of medication errors in drug compounding. To minimise the risk of errors at the dispensing stage, it is recommended that these 34 active substances are delivered in available licensed products. Comprehensive research is needed to better describe the profile of compounding prescription, so it can assist pharmacists in hospitals in formulating strategic steps to reduce the risk of medication errors due to drug compounding.

\section{Acknowledgements}

This study was funded by DRPM-RisTekDikTi with contract number: DIPA-042.06.1.401516/2019. The authors would like to thank the hospitals in the Wates area, Yogyakarta Special Region, and Danis, Kandela, Prima, Olin, Advent, Simon, There, and Gita, who had helped the authors with technical matters.

\section{References}

Gudeman, J., Jozwiakowski, M., Chollet, J., \& Randell, M. (2013). Potential risks of pharmacy compounding. In Drugs in R and D, 13 (1), pp. 1-8. https://doi.org/10.1007/s40268013-0005-9

Jackson, M., \& Lowey, A. (2010). Handbook of Extemporaneous Preparation A Guide to Pharmaceutical Compounding. Pharmaceutical Press

Kristina, S., Wiedyaningsih, C., Widyakusuma, N.N., \& Aditama, H. (2017). Extemporaneous compounding practice 
by pharmacists: a systematic review. International Journal of Pharmacy and Pharmaceutical Sciences, 9(2), 42-46. https://doi.org/10.22159/ijpps.2017v9i2.15681

Kristina, S.A., Wiedyaningsih, C., Widyakusuma, N.N., \& Aditama, H. (2018). Profile and determinants of compounding services among pharmacists in Indonesia. Asian Journal of Pharmaceutics, 12(3), 966970

Piliarta, I.N.G., Dewa, A.S., \& Noviyani, R. (2012). Kajian Kelengkapan Resep Pediatri Rawat Jalan yang Berpotensi Menimbulkan Medication Error di Rumah Sakit Swasta di Kabupaten Gianyar. Jurnal Farmasi Udayana, 1(1)

Rochjana, A., Jufri, M., \& Andrajati, R. (2019). Masalah farmasetika dan interaksi obat pada resep racikan pasien pediatri: studi retrospektif pada salah satu rumah sakit di Kabupaten Bogor. Journal.Unpad.Ac.ld, 8(1), 42-48. https://doi.org/10.15416/ijcp.2019.8.1.42

Setyani, W., \& Putri, D.C.A. (2019). Resep Dan Peracikan Obat. Sanata Dharma University Press

Virginia, D.M. (2014). PERESEPAN SEDIAAN RACIKAN PADA PASIEN ANAK DI BANGSAL RAWAT INAP. Jurnal Penelitian, 18(1). Available at: https://e-journal.usd.ac.id/index.php/JP/article/view/807

Widyaswari, R., \& Wiedyaningsih, C. (2012). Evaluasi Profil Peresepan Obat Racikan dan Ketersediaan Formula Obat untuk Anak di Puskermas Provinsi DIY. Majalah Farmaseutik, 8(3), 227-234. Available at: https://journal.ugm.ac.id/majalahfarmaseutik/article/view/24079/157 56

Wiedyaningsih, C., Widyaswari, R., Hasani, M., \& Dhani, W. (2012). Compounding Prescription Patterns: Factors Influencing the Physicians to Prescribe Compounded Medicines for Paediatric Outpatients. Research in Social and Administrative Pharmacy, 8(6), e29. https://doi.org/10.1016/J.SAPHARM.2012.08.067

Wiedyaningsih, Chairun, \& O. (2005). Investigation on drug dosage form : analysis of prescriptions available in pharmacy in kotamadya Yogyakarta. Indonesian Journal of Pharmacy, $\mathbf{0}(0)$, 201-207. https://doi.org/10.14499/INDONESIANJPHARMOISSOPP201207 